\title{
Airsoft Games as a Way of Reusing Post-military Areas
}

\author{
Adam Siniecki \\ Faculty of Architecture, Poznan University of Technology, Poland
}

Copyright $(2016$ by authors, all rights reserved. Authors agree that this article remains permanently open access under the terms of the Creative Commons Attribution License 4.0 International License

\begin{abstract}
The paper presents the results of a study on preservation of military facilities conducted in 2013 and 2014 at the Faculty of Architecture at Poznań University of Technology. The study focused on the issue of reusing and preserving former historic military buildings. The objective of the study was to verify the possibilities of adapting military areas located in the Wielkopolskie Voivodeship for the organization of games which more or less employ military tactics. The paper introduces a definition of paramilitary sports, which was created for the purpose of the author's doctoral dissertation. The results of the analysis of current trends in developing land for the purpose of Airsoft games are also presented. The data from the analysis were is an expert method applied to create a theoretical model of paramilitary sports. The model was then used to evaluate the former military facilities with respect to their adaption for Airsoft games. In correlation with the historic value of the analyzed facilities, the results of the evaluation allowed the author to produce a list of sites of military architecture in the Wielkopolskie Voivodeship that present great potential for the above mentioned purposes. The paper concludes that the theoretical model for paramilitary sports centers is an efficient tool for evaluating the suitability of prospective locations for Airsoft games and helps to properly develop the area in terms of its functionality and spatial lay-out. The results of the study proved that the model can be applied to all former military facilities in Poland that remain un-adapted. The study also presents the outcome of cooperation of the Faculty with the Military Academy of Land Forces in Poznan, and with the "Poznańczycy Group", which maintains one of the Prussian bomb shelters in Poznań.
\end{abstract}

Keywords Military Architecture, Post-Military Brownfields, Paramilitary Sports

\section{Introduction}

Sports, which to the uninitiated seem similar to military operations, are becoming ever more popular around the world. This is quite a new trend, as games such as Paintball or Airsoft only appeared here in the 1980s. This activity, which might come across as something hostile and aggressive, is in fact an apolitical and interesting way to spend free time. In research conducted at Poznan University of Technology's Faculty of Architecture, on account of their shared characteristics and similarities, they have been assigned a common title: "paramilitary sports". 1

It is assumed that both Airsoft games and Paintball ${ }^{2}$ are played by adults. Individuals under fourteen years old are prohibited from taking part. Whereas teenagers are older than fourteen have to obtain a written consent from their guardians. People up to 30 years old constitute the largest age group for these sports. Gameplay often entails pre-determined aims or tasks. Their completion requires cooperation between team members, strategic thinking, planning and anticipating the behaviour of enemies and allies. In the opinion of most players, this hobby is a source of positive emotions, a large dose of adrenalin and a way to temporarily forget everyday problems.

Paramilitary sports enthusiasts often choose forests, deserted industrial buildings, warehouses and former communist collective farms as meet venues. Most are unsecured and constitute a risk to players as well as other people. Despite efforts to clearly mark the game zones, there is always a risk that bystanders, forest mushroom pickers or hunters, not to mention wild animals will enter the area.

Former military facilities, near city boundaries, seem to be ideally suited to these types of activates. Their location is ideal: within easy reach of cities and yet at a safe distance from residential buildings. Thus, there is an opportunity for military facilities and the terrain (ditches, hills), which used to be important for the army and it's functioning, to be given a second lease of life in the hands of military enthusiasts. Paramilitary sports may activate ex-military facilities and as such continue the "military spirit of the place".

\footnotetext{
${ }^{1}$ I define them in subsequent parts of the article.
}

${ }^{2} \mathrm{~A}$ type of paramilitary sports 


\section{Research}

\subsection{Research Objectives}

The research aimed to develop a method for evaluating abandoned post-military areas in terms of their suitability to host Airsoft games. The works focused on coming up with a theoretical model for spatial and functional development of a paramilitary sports centre. A list of characteristic, priority buildings (military architecture historic monuments), with the largest paramilitary sports use potential was drawn up at the same time.

In determining the territorial scope for the search, accessibility to the research material and the necessary volume for analyses and site visits were taken into account. This leads to a decision to conduct research within the Wielkopolskie (Greater Poland) Voivodeship. Due to its location on the map of Europe as well as its rich history, the region has witnessed a number of wars and armed conflicts. There are numerous military facilities architecture facilities in Greater Poland. They stand testament to the evolution of fortifications over the ages.

A number of factors were significant in determining the age span of the facilities taken into account by the research. The first is the fact that the disused post military facilities, located in Poznań include buildings of historical significance erected at the tome Festung Posen was under construction. Some are unique on a European scale and depict the evolution of fortifications in the 19th and 20th centuries: starting with forts subsequently adapted by the Polish Army during the inter-war period and then transformed to reflect the needs of the Cold War period. For example, signs of each of the aforementioned epochs are visible in infantry bunker J1 VIIIa et al. Babimojska and Fort VIIa et al. Marcelińska in Poznań. Looking closely at the evolution of defensive architecture a clear tendency to gradually reduce architectural details is noticeable ${ }^{3}$. Thus it was necessary to determine an age span for the analysed fortifications. The boundary date is 1828 , when construction of Festung Posen fortifications began on the basis of major Johann von Brese's designs. Research spans the period up to 1993, when, following withdrawal of the Russian Federation's army from military bases, more than 56 thousand hectares of former military areas were returned to polish hands and a further 20 thousand hectares were released by the Polish Army [2].

The relatively long research period makes it possible to demonstrate post military facility diversity in terms of architectural and historic value, size, form and function. The three developed paramilitary sport centre models facilitate the most efficient use of ex-military areas.

Scientific goals have been set associated with protecting the cultural heritage of Greater Poland. These include surveying post military areas in the Wielkopolskie

\footnotetext{
${ }^{3}$ The complex of two bunkers in Poznań at ul. Wrzesińska is a clear example. The ammunition schelter M IIIa, built between 1887-1890, had mansory façade with decorative ornaments. In 1903 was added another schelter A IIIa without decorations [1]
}

Voivodeship and drawing up a list of unused and abandoned ex-military facilities (brownfields). Determining the architectural and historic value of unused former military facilities makes it possible to establish a list of "more recent" military architecture historic monuments in Greater Poland. Whereas evaluating post military brownfields in terms of adapting for paramilitary sports centres, made it possible to identify the facilities most suited for the aforementioned purpose.

Furthermore, airsoft environment development goals have all been set within the scope of the research. The current trends within the scope of organising Airsoft games were analysed and boundary conditions for the game courses in terms of player and bystander safety were determined.

As the developed model may be used for all post military brownfields in Poland and abroad, works constitute application research.

\subsection{Thesis}

In conjunction with the problem of general deterioration of ex-military architecture, the following research question surfaced: How is it possible to stem the deterioration of military architecture historic monuments and use those facilities within the framework of urban activation of the area?

The search for an answer to the above question led to the formulation of the above thesis: Correct spatial development and hosting of airsoft games in abandoned military bases constitutes an effective tool to protect and look after military architecture in Greater Poland.

\subsection{Methodology}

I adopted the following research schedule to prove the thesis.

\begin{tabular}{|c|c|}
\hline Stage I & $\begin{array}{c}\text { Identification of facilities which are historic monuments } \\
\text { and require protection }\end{array}$ \\
\hline Stage II & Conduct an architectural evaluation of those facilities \\
\hline Stage III & $\begin{array}{c}\text { Define the adaptability of former military architecture } \\
\text { for the needs of Airsoft games }\end{array}$ \\
\hline Stage IV & Perform ad hoc experiments \\
\hline Stage V & Construct a model of a paramilitary sports centre \\
\hline Stage VI & Synthesis of analytical material, conclusions \\
\hline
\end{tabular}

The research comprised literature and archived data analyses; site visits to venues in Poland where Airsoft games are hosted; site visits surveys of post military areas; quality research of centres in Poland and abroad; questionnaire based surveys (expert method); evaluating criteria using the peer group method; questionnaire based surveys (for 109 Airsoft players on the quality of post military areas); collection of photographic evidence (1600 photographs); architectural evaluation of former military facilities; ad hoc experiments; „research by design” method.

The above are standard methods. The use of ad hoc 
experiments is noteworthy as well as the „research by design” method, which were used to construct a theoretical model of a paramilitary sports centre.

\subsection{The State of the Art within the Scope of Military Architecture Research}

A selection process taking into consideration time and substance was applied to Military and armed forces engineering research achievements. 1828 was the time boundary - commencement of the construction of Festung Posen. The 18th century saw an intense development of defensive systems in Greater Poland which was part of the Kingdom of Prussia. New fortification schools appeared during that period, developed by such renowned fortifications architects as Mougina (France), Maksymilian Schumann (Germany), Henri Alexis Brialmont (Belgium) and Eduard Totleben (Russia).

Numerous Polish and foreign popular science and professional reports have been devoted to pre 1914 fortifications. Great War and World War II fortifications have been thoroughly documented, and this is particularly true for defensive lines which played important roles in military operations. The "more recent defensive architecture", which appeared after 1945, is least documented.

The aforementioned Joseph E. Kaufmann is a respected American fortifications expert. Apart from the "Fortress Third Reich" well known in Poland, "Fortress France" 4 "The Maginot Line" ${ }^{5}$ and "The Atlantic Wall" 6 are also noteworthy. The first two focus on defensive systems in France from the interwar period. The latter presents Hitler's defensive wall along Europe's western coastline. Kaufman also wrote the „Fortress America: Forts that Defended America" monograph where he presents the development of the defensive system in the United States on North America from the 1790s to the Second World War. The Author pays particular attention to the defensive role played by coastal forts located at entry points to commercial ports.

„Bunker Archeology” [3] by Paul Virilio - a French cultural theoretician and urban planner presents results of research conducted in 1958 within the French section of the Atlantic Wall. It is a valuable source of cartographic and photographic documentation of the Nazi defensive system. The author's deliberations on the role played by Albert Speer, "Hitler's architect" in the creation of the III Reich are the backdrop for discussing bunkers and defensive systems.

There are many publications which describe defensive systems in given countries. Works by Rob Wolfs on the Dutch Waterlinie Defence Line [4] or Wim Klinkert

\footnotetext{
${ }^{4}$ In the book Kaufmann presents a thesis, that the between 1939 and May 1940 Maginot Line could have fulfilled its designation, giving the French command ample possibilities of making use of it.

5 co-authors: Hanna W. Kaufmann i A. Jankovie-Potoenik. Book published in the United Kingdom.

${ }^{6}$ co-authors: Hanna W. Kaufmann, A.Jankovie - Potoenik, Vladimir Tonie Book published in the United Kingdom.
}

pertaining to the Dutch defensive plans and strategies over the ages are good examples [5]. Professor Klinkert authored books and numerous articles on Dutch military architecture dating back to the First and Second World Wars.

The revitalisation process of abandoned military areas and their use for new public and residential functions in The Czech Republic was described by authors such as: Hercik Jan, Šimáček Petr, Szczyrba Zdeněk, Smolová Irena [6], Szczyrba Zdeněk [7], ŠerýOndřej, Toušek Václav[8]. Nepravishta Florian [9] used Albanian projects as the basis to preset the same issue in his article. Implementation of an EU programme in Romania, entitled „From Army to Entrepreneurship", was described by Simon Bar, Alexander Antal and Marian Barbu [10].

A very useful report by the US Environmental Protection Agency „Turning Bases: Into great places: New Life for Closed Military Facilities" [11] is noteworthy, despite it not being a scientific publication. The document assumes the form of a guidebook - an instruction manual for the community, state authorities and American businessmen, faced with the problem of shutting down military bases. All the activities, which should be performed in order for the revitalisation and economic activation processes to be successful are explained step by step. Alternative solutions are also presented, which, both lead to an improvement to economic and social conditions and are environmentally friendly.

The „Monumentsmilitairesdans le domaine des Forcesaériennes" brochure was published by the Swiss Federal Department of Defence, Civil Protection and Sport. The publication presents the history of national military aviation, genesis of The Military Aviation Museum coming into being and constitutes a list of facilities associated with military aviation, which should be kept and merit heritage protection.

Most publications describe fortifications from the turn of the 19th century. There is a considerable delay when it comes to research on military architecture and engineering structures, due to limited access to the sites. In most cases, prominent military engineering achievements are described once the primary function is lost, or when the army decommissions them. However, this does not belittle their importance to the development of military art and national cultural heritage.

The negligible numbers of articles on Polish military architecture dating back to 1949-1989 takes root in the fact there access to that historic and archive materials, as well as the facilities themselves is severely limited. This is understandable as most are still used by the Polish Army. Others, on account of their age, are too recent to be subject to historic research. Their location - surrounded by forests, means they are not very visible - and as such, not attractive. Often they also constitute a relic of an age gone by, which the society is trying to forget. 


\section{Abandoned Post-military Facilities in the Region of Greater Poland}

\subsection{Post-military Facilities}

Due to its location on the map of Europe as well as its rich history, the region of Greater Poland has witnessed a number of wars and armed conflicts. For this reason, it is pitted with disused military facilities, which pictures the evolution of fortifications that happened over a span of centuries.

Ineffective strategies for preserving and reusing such places lead to the devastation of valuable historic post-military facilities. Fortifications that survived from the times of Festung Posen are unique on a European scale. Yet, they have been left to deteriorate. Fine examples of the Polish military engineering of the 1920s and 1930s are falling into ruin. Forgotten military complexes and bases slowly disappear, remaining hidden deep in the woods or being ransacked and damaged. In relation to the prevalence of degradation, the following research question was formulated: how to cease the process of degradation of historic post-military facilities and then re-employ them to provide urban stimulation of their surroundings?

In the region of Greater Poland, there are several dozen recently decommissioned military facilities, including proving grounds (in the vicinity of Okonek), shooting ranges (e.g. in Biedrusko and Gniezno), bases of air defense missile divisions (five bases surrounding Poznań), posts of signal corps, military airplane guidance stations (e.g. in the vicinity of Września), fuel and lubricant depots, as well as barracks and military staff buildings.

The evolution of military strategies and tactics, the improvement of conventional weapons, the development of new types of weaponry, and the advancement of military technology ultimately deprived many facilities and complexes of their military function. The upheaval in the construction of fortifications was imposed by the introduction of aviation to the battlefield. Changes in the political systems of Central European and Eastern European countries that were taking place in the 1990s resulted in vast numbers of military premises, located both in urban areas and woodlands, being vacated by the army.

Since 1990, the Polish Armed Forces have been undergoing the process of restructuring and modernization. The replacement of obsolete equipment is accompanied by infrastructural changes. Decommissioned military facilities have been transferred by the Military Property Agency into commercial real estate. Some of them were returned to the State Forests, while others were traded or handed over to local self-governments [2]. Unfortunately, change of ownership usually leads to further deterioration rather than improvement. Unprotected facilities are ransacked, damaged, or demolished. Regardless of their historical value, they gradually disappear among greenery or make room for new residential developments. These places are not mentioned anywhere else than on websites administered by military enthusiasts or web portals that gather ex-soldiers.

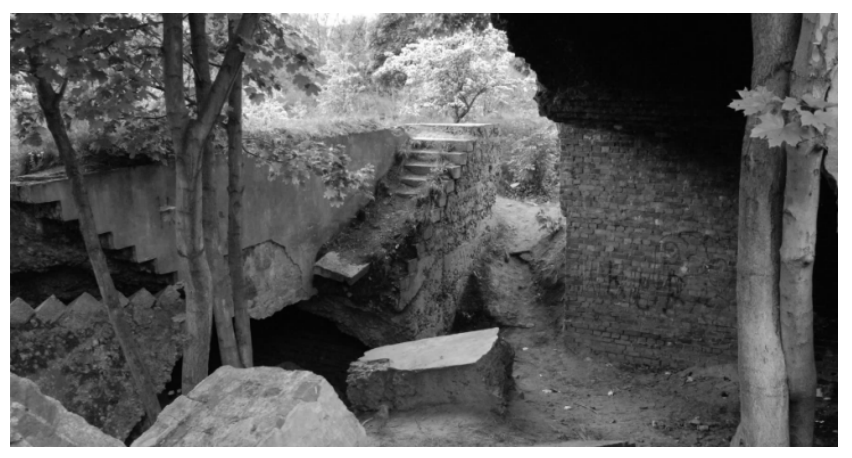

Photograph 1. Fort IV in Poznań (author: A. Siniecki).

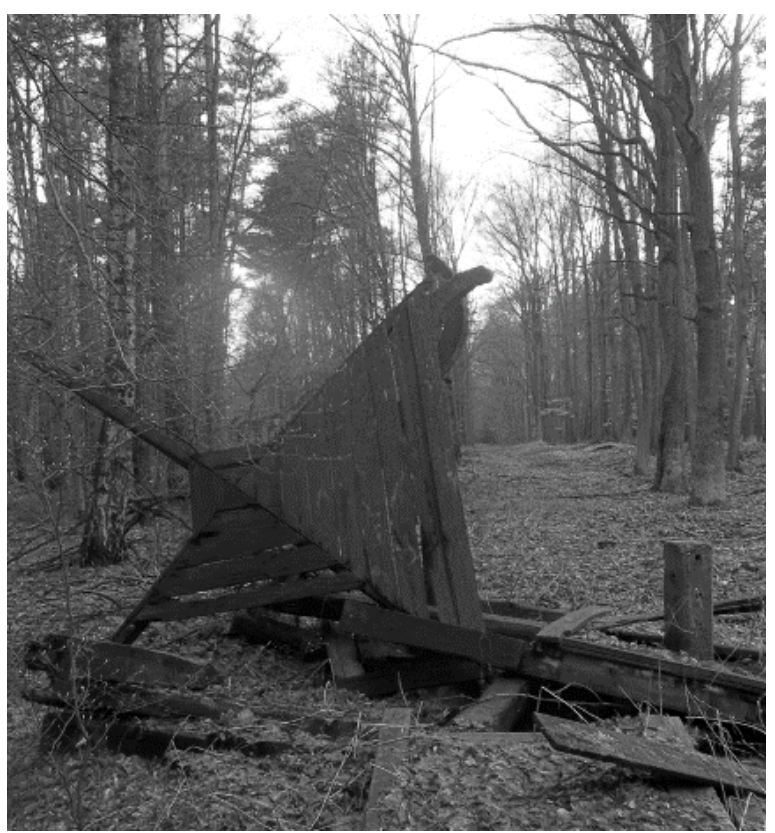

Photograph 2. The decommissioned base of the 31st Air Defense Missile Division in Czołowo near Kórnik (author: M. Janowski).

One of the most common solutions for protecting valuable examples of military architecture is the establishment of culture parks, where the historic military facilities can retain their original form and help educate young generations. Transformation of such places into museums or memorials is the best possible way of honoring their historical value. This kind of protection should be employed for the most valuable and most important historical sites. Another common way of re-employing former military buildings is the conversion into residential premises, which entails a more severe interference in the historic architecture. Across the world, improving, remodeling, and re-employing to new uses remain among the most popular methods for preserving historic military facilities. However, due to the diversity - in terms of location, form, function, and time of construction not all post-military sites are suitable for such transformations or high costs of such conversions make them economically inviable. 


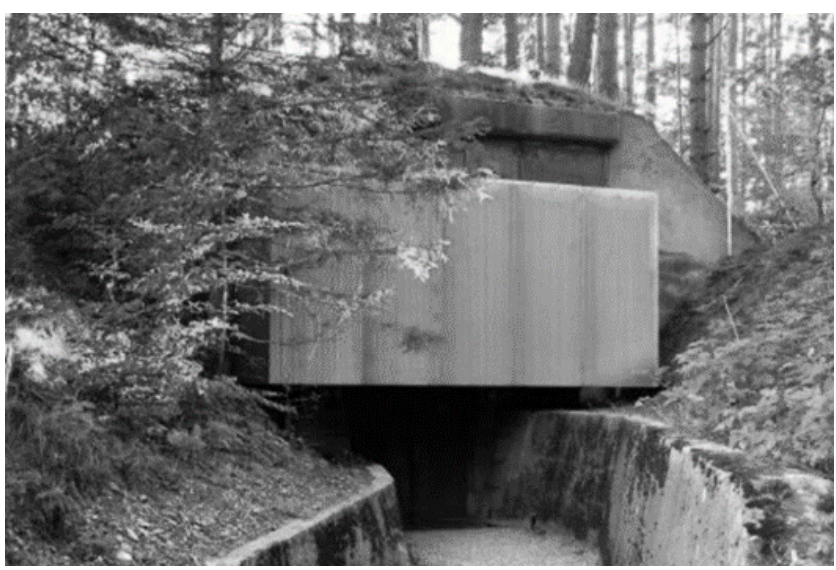

Photograph 3. The Angebauter Tarnrucksack Cultural Center located in the former World War II bunker in Fläsch, Switzerland [12].

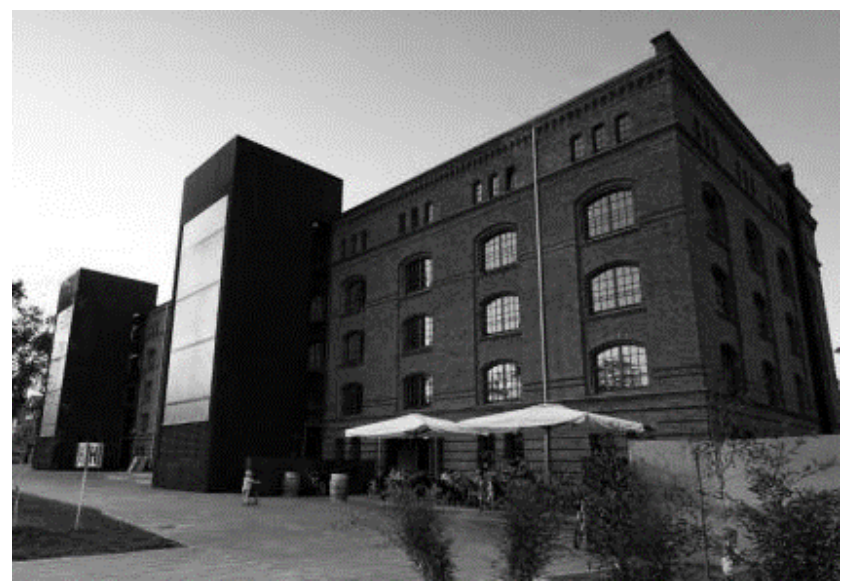

Photograph 4. Granary lofts in historic barracks in Gliwice (design: Meduza Group) [13].

The potential for revitalization of decommissioned military facilities has been already noticed by an array of EU institutions. Economic stimulation of post-military areas provides an opportunity for erasing differences between regions $^{7}$ [14]. In the United States, the Office of Economic Adjustment (OEA) has been supporting local communities in developing sustainable strategies for re-employing abandoned military bases since 1961 [15]. The above-mentioned undertakings are aimed at putting the economic potential of such areas to work and therefore they are prepared for commercial or residential development. According to the OEA's report that was published at the end of 2007, these actions provided more than 140,000 new jobs in 73 decommissioned military bases [16]. In such cases, the recommended practice is the employment of historical and military values of buildings located in defunct bases in the development of regional tourism. Across the world, the phenomenon known as heritage tourism keeps gaining popularity, especially its sub-branch that is oriented towards

${ }^{7}$ Participants of consecutive editions of the INTERREG program benefit from knowledge and experience of those cities that have already been successful in re-employing disused military facilities. Examples of such cities include Utrecht in Denmark, Cartagena in Spain, and Medway in Great Britain [14]. military history. Gatherings of military enthusiast and historical reenactments are attended by crowds of visitors. Such events are organized in Poland, as well, e.g. the yearly military vehicles show in Borne Sulinowo, the Poznań Fortress Days, and annual reenactments of the Battle of Warsaw. However, despite their reputation and rather good publicity, these events do not provide post-military facilities with the year-long occupation. What is needed is a concept that would enable historic sites to thrive regardless of the season.

\subsection{Classification of Decommissioned Facilities}

Within the framework of the study that was being conducted at the Faculty of Architecture of the Poznan University of Technology, 43 decommissioned military facilities were examined, all of them located in the region of Greater Poland. The list of facilities to be examined had been created on the ground of information acquired from the Military Infrastructure Administration in Poznań, the Military Property Agency (Gorzów Wielkopolski Branch), the Military Academy of Land Forces in Poznan, the Land Forces Training Center in Poznań, publications listed in the bibliography, available maps, archives, and websites administered by military and history enthusiasts.

In accordance with the Polish Classification of Buildings (PKOB), they had been categorized as Military Engineering Structures (e.g. forts, blockhouses, bunkers, rifle ranges, proving grounds, military research centers, launch pads), Barracks, Military Aviation Units (e.g. buildings for transportation and communications), and Other (remaining beyond the defined subgroups).

\subsection{Architectural Indexation of Post-military Facilities}

The second stage of the study consisted in the architectural indexation of post-military facilities. It was based on the literature study as well as consultations with the Regional Historic Preservation Officer, the Military Infrastructure Administration, and the Military Property Agency.

The evaluation was carried out with allowance for the following two criteria: time of construction and technical and functional values. Particular attention was directed towards technical or spatial solutions that remain unique on a domestic or European scale. On the ground of gathered materials, the author of this paper carried out an indexation of examined facilities with the use of a five-point grading system. This led to the production of a list of 12 post-military facilities that exhibit great historical value: the secret Soviet base with the nuclear missile depot in Brzeźnica-Kolonia, Forts Ia and VIIa in Poznan, infantry shelters at Minikowo street and Babimojska street in Poznań, the interfield shelter of Fort II in Poznan, the weir on the Cybina river in Poznan, the bomb depot in Stara Łubianka, the former base of the Air Defense Missile Division in Złotkowo, barracks in Piła, and two examples of officers' mess halls - one in Biedrusko, and the other one in Śrem. 


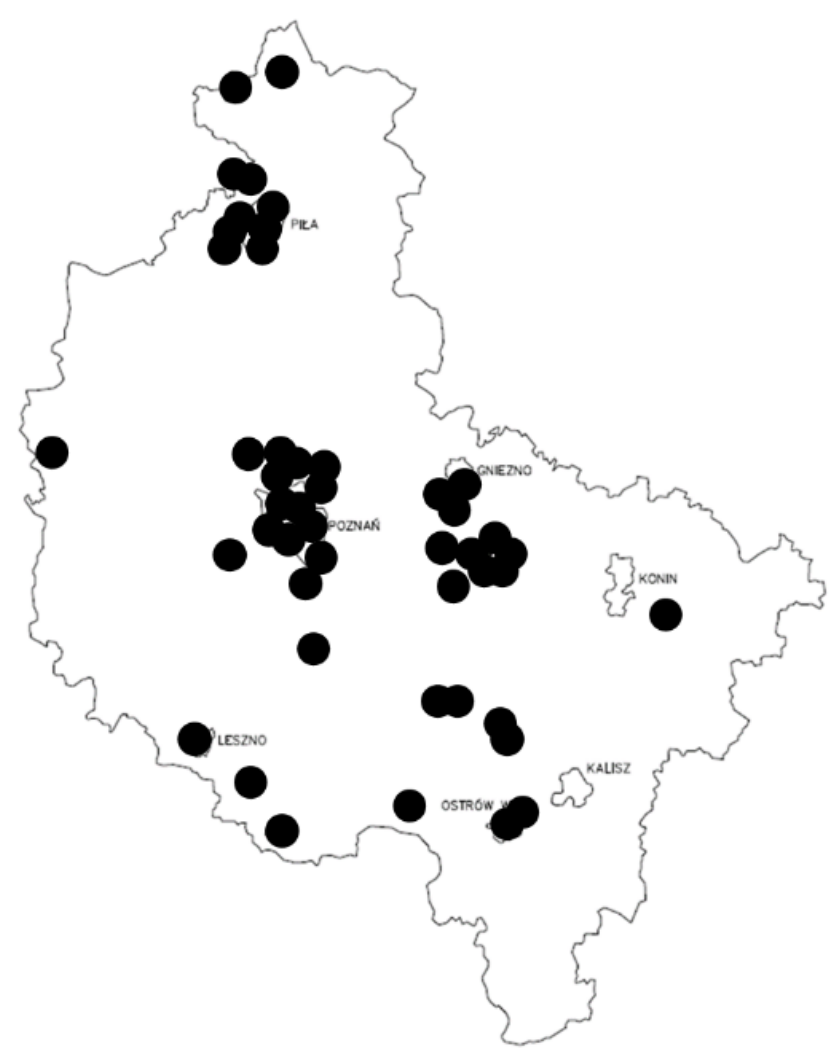

Figure 1. Location of all 43 decommissioned post-military facilities (Author's own work).

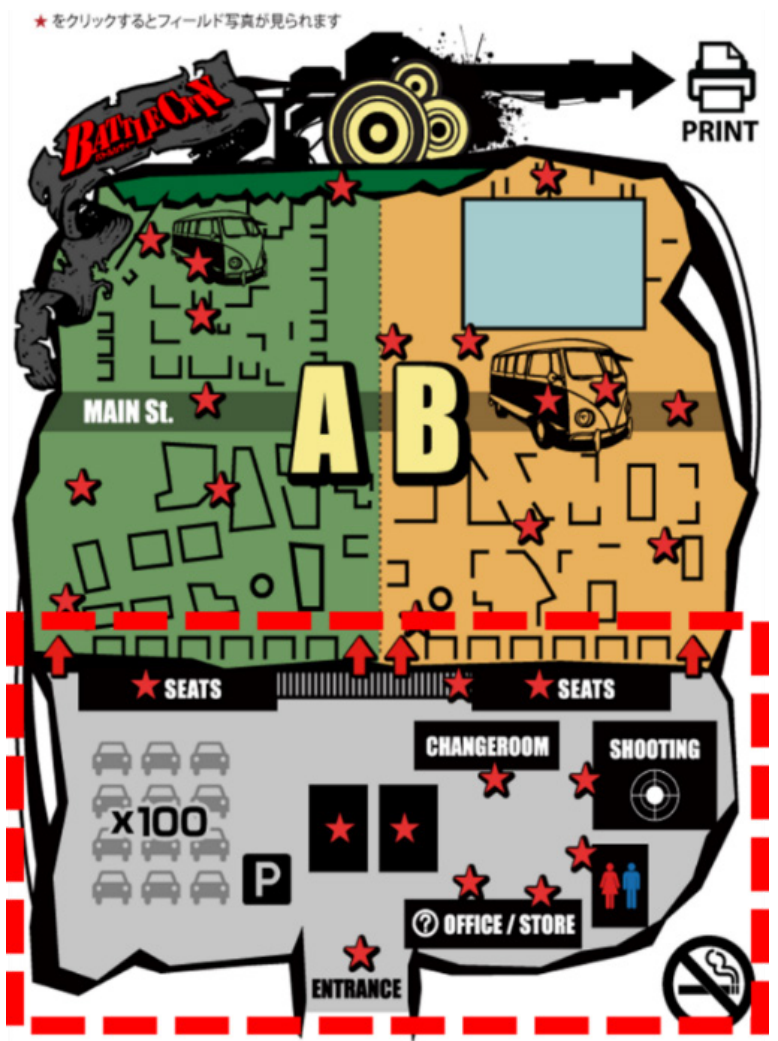

Figure 2. Schematic drawing of the Battle City, with the marked safe zone [17]

Location of the facilities in Greater Poland subject to the research is shown on the map below (Fig. 1). Some are located within the Poznań County. Poznań is primarily home to historic 19th century Festung Posen fortifications: multi-level forts spanning varied terrain and significantly smaller bunkers with simple spatial layouts. Former national air defence divisions' facilities are located around the city. These formations, as well as the forts, comprised a ring around the Poznan agglomeration. The functional and spatial layout of each base is identical. Located in forested areas with barracks on flat ground and the combat zones camouflaged in forests. Due to the time of its construction, modernisation efforts dating back to various periods, diversity in terms of functions and forms, military architecture throughout the Poznań agglomeration constitutes an important example of defensive systems evolution.

The Piła commune constitutes another concentration of post military facilities. Both structures and infrastructure which were used by 6th Fighter - Bomber Regiment in Piła can be found there [18]. These are facilities which played various functions, from barracks, through utility and warehouse buildings all the way to undeveloped plots adjacent to the airfield and the military base. They differ in terms of area, terrain and development.

The last large complex comprises facilities associated with military aviation in Powidz near Stupca. All researched examples constituted technical services for the base. These include electric beacons as well as fuels, lubricants and associated products warehouses. The form and the location of these structures were dictated by their functions.

\section{Paramilitary Sports}

\subsection{Definition}

For the purpose of this study, the author has adapted the following definition of paramilitary sports:

Paramilitary sports are apolitical group games that involve military tactics to various degrees and consist in eliminating opponents by hitting them with different types of ammunition. Depending on the discipline, emphasis can be placed on the realistic tactics as well as the appearance of firearm replicas, players' apparel, and other equipment. Paramilitary sports include the following types of games: NERF, Laser Tag, Paintball, and Airsoft games.

The above definition was compiled on the ground of the explication of the term paramilitary organizations provided by Piotr Socha, Sergeant at the Polish Rifleman's Association [19], and the interpretation of the word paramilitary published by Professor Mirosław Bańko [20] in the PWN's online dictionary of the Polish language.

\subsection{Evaluation of Adaptability of the Historic Military Architecture to the Needs of Airsoft Games}

The next stage of the study was the evaluation of 
adaptability of the historic military architecture to the needs of airsoft games. Among other paramilitary disciplines, airsoft is distinguished by the most realistic imitations of uniforms, weapons, and other pieces of equipment, as well as the game field behavior that reflects real military tactics. Airsoft groups attract history and military enthusiasts, who frequently specialize in historic reenactments, specifically those associated with World War II, Vietnam War, or contemporary armed conflicts.

According to the study conducted by the Center for Airsoft Statistics and Player Relations in 2013 [21], this discipline is practiced mostly by young people who are well-educated and belong to the group of high earners. Professional airsoft communities operate in Japan, Korea, United States, and Western European countries. A considerable number of airsoft enthusiasts travel the world to participate in the most important and esteemed competitions, such as the Border War in Ralsk in the Czech Republic, which is held on a former military proving ground. Each year, the event attracts around 1300 players from around the world. According to the report, airsoft remains an elitist sport. The average spending of airsoft players (firearm replica and basic gear) ranges from $\$ 1800$ to $\$ 2700$. This sum could be easily doubled by the purchase of GPS devices, night vision devices, grenade launchers, pyrotechnics, and special vehicles, as well as the costs of traveling and event fees.

Figure 2 presents an airsoft game field by using the example of the Battle City Union, a reputable airsoft center in the city of Chiba in Japan. A division into the game zone (on top) and safe zone (on the bottom of the diagram) is visible. It is possible to divide the $15,000.0 \mathrm{~m}^{2}$ game course into two sections. This makes it possible to host two sports events at the same time. There are ground floor buildings on the game course, with streets and a square, as well as vehicles, various kinds of obstacles and a pond. The gameplay can be watched from stands The safe zone includes a car park for 100 vehicles, a helipad, changing rooms, toilets and bathrooms, food and drink facilities, an office and a shop as well as an area for testing replicas. The centre provides its customers with transport in the form of two busses and a helicopter. The fact that the safe zone generates the biggest income, which supports the game course, is noteworthy. That is why it is so important for the programme of this zone to be as varied as possible.

Table 1. Summary of the survey results concerning the green tactics (outdoor) facilities (part 1 out of 3 )

\begin{tabular}{|c|c|c|c|c|c|c|}
\hline & & $\begin{array}{l}\text { Battle } \\
\text { Arena, } \\
\text { Poland }\end{array}$ & $\begin{array}{c}\text { Centrum Rozrywki } \\
\text { Militarnej } \\
\text { WOLA-CAMP, } \\
\text { Poland }\end{array}$ & $\begin{array}{l}\text { GO-SYSTEM, } \\
\text { Poland }\end{array}$ & $\begin{array}{l}\text { BLACKFIELD, } \\
\text { Germany }\end{array}$ & $\begin{array}{l}\text { The highest-grade } \\
\text { parameter used in the } \\
\text { theoretical model of a } \\
\text { paramilitary sports } \\
\text { center }\end{array}$ \\
\hline No. & Categories: & \multicolumn{4}{|c|}{ Examined airsoft centers: } & Results \\
\hline $\mathrm{K} 0.1$ & $\begin{array}{l}\text { Distance from the voivodeship's } \\
\text { capital }\end{array}$ & 3,33 & 2,11 & 3,11 & 1,89 & \\
\hline $\mathrm{K} 0.2$ & Distance from the district's capital & 3,56 & 3,33 & 3,56 & 3,00 & \\
\hline K0.3 & $\begin{array}{l}\text { Is the area designated as a listed } \\
\text { facility? }\end{array}$ & 3,33 & 3,89 & 3,89 & 3,56 & \\
\hline K0.4 & Size of the plot: & 3,56 & 4,78 & 4,44 & 4,11 & 256700 sq. m. $(4,78)$ \\
\hline $\mathrm{K} 1$ & ACCESS AND PARKING LOT & & & & & \\
\hline $\mathrm{K} 1.2$ & Asphalt-paved driveway & 4,56 & 2,78 & 4,56 & 4,11 & Asphalt road \\
\hline $\mathrm{K} 1.3$ & Number of parking spaces & 4,11 & 3,89 & 4,67 & 1,67 & $180(4,67)$ \\
\hline $\mathrm{K} 2.1$ & OFF-GAME ZONE & & & & & \\
\hline $\mathrm{K} 2.2$ & Sanitary facilities & 4,56 & 4,56 & 3,44 & 4,44 & Yes $(4,56)$ \\
\hline $\mathrm{K} 2.3$ & Locker rooms & 4,11 & 4,11 & 2,56 & 4,11 & Yes $(4,11)$ \\
\hline $\mathrm{K} 2.4$ & Catering outlet & 1,56 & 3,89 & 3,89 & 1,67 & \\
\hline $\mathrm{K} 2.5$ & $\begin{array}{l}\text { Recreation facilities (bonfire, } \\
\text { barbecue, tables and benches) }\end{array}$ & 4,22 & 4,22 & 4,11 & 4,22 & Yes $(4,22)$ \\
\hline $\mathrm{K} 2.6$ & Command post for the players & 1,67 & 1,67 & 4,00 & 1,11 & Command post $(4,00)$ \\
\hline $\mathrm{K} 2.7$ & Office & 3,33 & 1,89 & 1,89 & 1,89 & \\
\hline K2.8 & $\begin{array}{l}\text { Storage room (for the equipment, } \\
\text { obstacles, etc.) }\end{array}$ & 1,33 & 4,22 & 3,78 & 4,00 & Storage room $(4,22)$ \\
\hline
\end{tabular}

49 categories graded by experts with the use of the $0-5$ point system

Objective selection of the most optimal parameters for respective zones of a paramilitary sports center

Examples of an expert survey of four airsoft centers. The complete results from the survey are presented in the doctoral dissertation by A. Siniecki: "The organization of paramilitary sports as a way of protecting historic military facilities, as exemplified by airsoft games" (Author's own work). 
The functional and spatial indexation of 20 airsoft game fields located both in Poland and abroad, was carried out. Each center was examined from the following four angles: access and parking lot (K1), off-game zone (K2), game field (K3), and safety (K4). Each of the 20 centers was examined by the group of 10 experts in terms of 49 criteria with the use of the $0-5$ point system. The considered criteria include, among others: the size of the center, the number of parking spaces, the off-game zone furnishings (sanitary facilities, locker rooms, and recreational facilities), the size of the game field, the number of buildings, and the architectural attractiveness, the lay of the land, and the number and type of obstacles. The survey results facilitated the objective selection of the most optimal parameters for respective zones of a model paramilitary sports center.

The same survey results were then used by the author of this paper for the purpose of examining 43 post-military facilities, all located in the region of Greater Poland, from the above-mentioned four angles with the use of the 0-5 point system. This resulted in the identification of 7 facilities that show the greatest potential for being adapted as paramilitary sports centers: the fuel and lubricant depot in Babina, garrison firing ranges in Biedrusko and Witaszyce, the Soviet base with the nuclear missile depot in Brzeźnica-Kolonia, Forts Ia and VIIa in Poznań, and the bomb depot in Stara Łubianka.

\section{Theoretical Model of a Paramilitary Sports Center}

The results from expert surveys helped to objectively specify the most optimal parameters for respective zones of paramilitary sports centers.

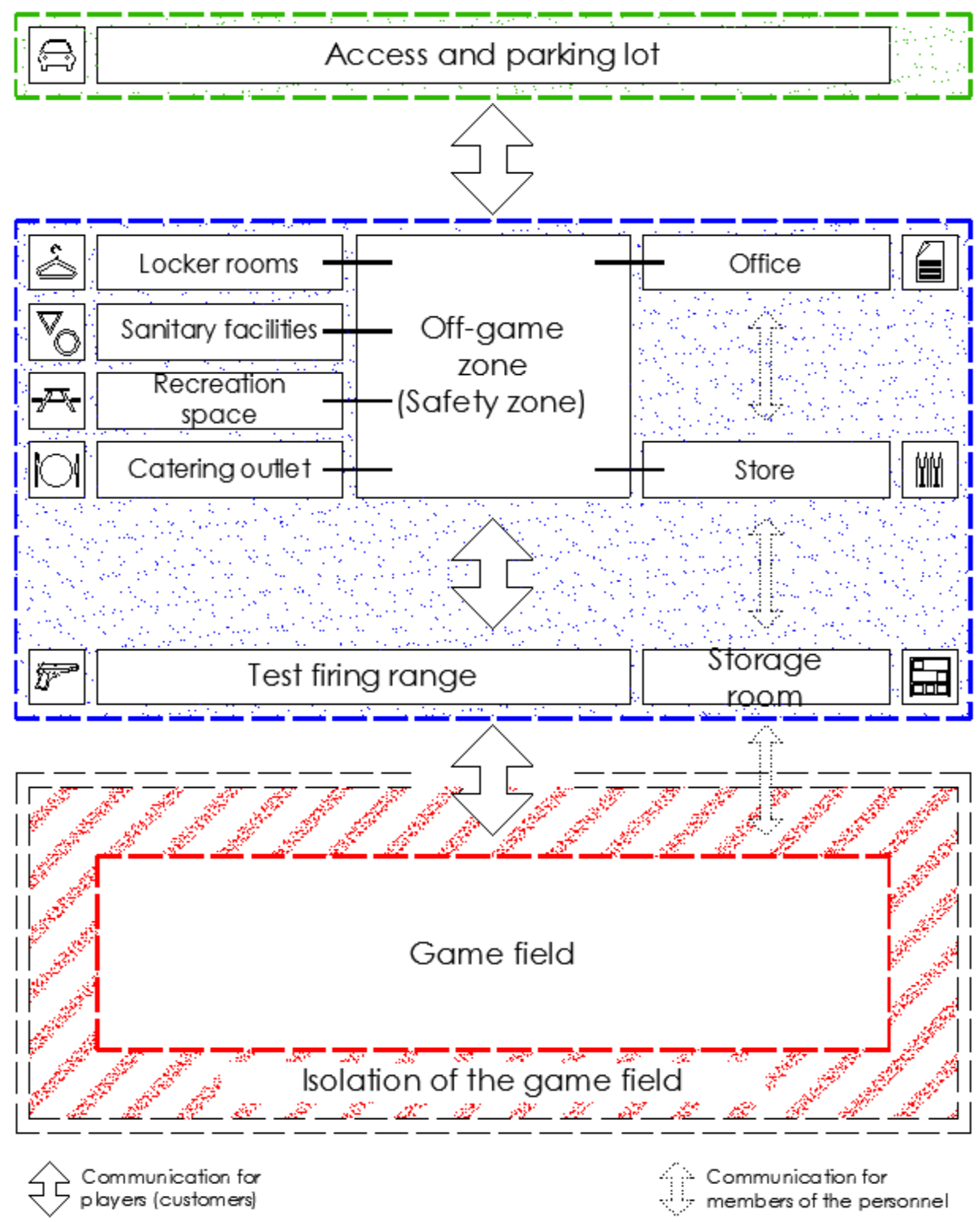

Figure 3. Schematic drawing of the functional and spatial model of a paramilitary sports center (Author's own work) 


\subsection{Access and Parking Lot}

Regardless of the facility's nature, the most coveted type of access road is the one paved with asphalt concrete. It should not exceed several hundred meters in length. The number of parking spaces depends on the location and preferred tactics.

CQB facilities are usually located in urban areas. Spatial restrictions of indoor facilities and the resulting limited capacity of a game field, translate directly into the number of available parking spaces. Similarly to their foreign equivalents, there is a tendency among Polish providers of CQB game fields to lease halls in commercial or warehouse complexes, and thus make use of a large common parking lot with more than 50 parking spaces ${ }^{8}$. In case of halls, where the game field does not exceed 1200-1400 sq. meters $(13,000-15,000$ sq. feet), the coefficient is 4 parking spaces for each 100 sq. meters of the game field.

Those centers that offer outdoor CQB facilities are located in the suburbs of large cities or in rural areas. The size of respective zones, as well as the parking lot, depends on the plot's total area. For the highest-graded centers, where the area of the game field amounts to $14,000-15,000$ sq. meters $(150,000-160,000$ sq. feet), the coefficient is, respectively, 0.3 and 0.6 parking space for each 100 sq. meters of the game field ( 3 and 6 parking spaces for each 1000 sq. meters). The limited capacity of parking lots also results from the fact that due to the remote location of such centers, large numbers of players share cars while traveling to the game field.

Those centers that are oriented towards woodland or open-field games, and are usually located far from large cities, have parking lots that are ready to accommodate more than 100-180 passenger cars. Thanks to this, such facilities are capable of organizing airsoft events and historical reenactments. In case of these centers, the coefficient is approx. 0.1 parking space for each 100 sq. meters of the game field (1 parking space for each 1000 sq. meters) ${ }^{9}$.

\subsection{Safe Zone / Off-game Zone}

In order to maintain its basic functionality, the center should provide locker rooms, sanitary facilities, the storage room, and recreational facilities (such as benches, tables, bonfire spots, barbecue stands). The presence of a briefing room / command post, where players can discuss the game's strategy and then make necessary adjustments on the go, was perceived as a positive feature only in large outdoor centers that are oriented towards green tactics.

Catering outlets or small diners located within the center are required in outdoor black tactics facilities. Still, it depends on the location of particular centers. City-based airsoft halls are usually surrounded by a great number of small diners and restaurants. Most players do not stay in longer than several hours, and the commute takes them less than an hour. On the other hand, large rallies and airsoft events frequently span several consecutive days (mostly over the weekends) so the players bring their own tents and food. What is more, such facilities usually fail to provide proper infrastructure for catering outlets.

The similar issue is observable in terms of administration offices. According to the experts, the offices should be located within airsoft halls. However, they are not required in larger centers. This provides for practicality since the customers who are interested in the organization of large events do not have to travel out of the city in order to meet the manager of the center.

\subsection{Game Zone / Game Field}

Most differences between respective airsoft centers are visible in the game field. The field's size and form depends on the employed tactics and nature of the given facility. Furthermore, a game field may be divided into built-up areas, woodlands, and open fields. The centers that are oriented towards green tactics tend to place emphasis on the presence of natural obstacles: rivers, water bodies, fallen trees, thick vegetation, and the diversified lay of the land. Additional obstacles should only complement the natural landscape, e.g. bridges, roadblocks, and fencing with gates. Such places frequently prove to be strategic in the game's scenario. Potential buildings should be formed as architectural complexes. Capacity of such game fields should amount to at least 300 players.

The black tactics, which involve close quarter battle, have been devised chiefly for competing in urban areas. Therefore, most centers are developed in the likeness of small towns with buildings, municipal squares, and streets filled with cars. The game field should cover green areas, preferably with a water body of some sort. The field's area should roughly amount to 1.5 ha (around 3 acres) in case of outdoor facilities and remain compacted to $1200-3000$ sq. meters $(13,000-32,000$ sq. feet) for covered fields.

\subsection{Safety}

All examined centers revealed the need to make the game field inaccessible to outsiders. The center should be isolated from other buildings, and preferably fully fenced. While surveying, much attention was paid to the issue of securing the game field, removing or marking any places that could pose hazard to life or health of the players (openings, wells, protruding rods and metal elements). Extra points were awarded to those establishments that provided landing pads for air ambulances.

\footnotetext{
${ }^{8}$ This is perfectly exemplified by Killhouse in Warsaw (more than 30 parking spaces) and Republika ASG in Wrocław (50 parking spaces).

The largest airsoft center among the examined facilities (Wola Camp), with the total area of 26.6 ha ( 65 acres), had the coefficient of 0.4 parking space per 1000 sq. meters of the game field.
} 


\section{Summary}

The main objective of the study consisted in the devising of a theoretical model for functional and spatial development of paramilitary sports centers. On the ground of the analysis of current tendencies in shaping airsoft game fields, the expert survey, and the evaluation of criteria that was carried out by competent judges, three models have been developed, each one complying with the specific nature of paramilitary sports.

The usefulness of the theoretical model was confirmed in the process of three experiments that had been carried out in two former military facilities and the military proving ground in Biedrusko. From the results of conducted analyses, the following conclusions have been drawn:

1. The greatest adaptability is exhibited by the decommissioned military bases. The area of the plot allows sensible development of the available space. In certain variants, it would be possible to adapt a single facility for both the green tactics (firing zone) and the black tactics (barracks). This enables the organization of two concurrent smaller events or one bigger.

2. Areas that used to be occupied by the military technical infrastructure (e.g. radio beacons, signal corps posts) are not suitable for being employed as paramilitary sports centers. Factors, which prove disadvantageous, include the limited area of such places, the proximity of neighboring buildings, and the presence of outsiders (local residents, strollers, mushroom pickers, and hunters).

3. Access roads had been constructed to accommodate large vehicles. In most cases, these roads survived in rather good condition and do not require any maintenance or upgrading. What is more, each base provided a parking lot for officers' private cars.

4. Large distance from the nearest buildings increases the safety of organized games. Decommissioned proving grounds and garrison firing ranges feature earthen structures, such as embankments or backstops, which provide additional protection of outsiders and passers-by.

5. In terms of architectural and historical attractiveness, it is noticeable that older facilities (Prussian fortifications), including buildings, are clearly more detailed. Newer structures that were erected after World War II, were based on standard designs, where functionality was imperative, and were usually constructed with precast concrete units. However, there are some exceptions to this rule, such as the former base of the 77th Air Defense Missile Division in Złotkowo. The buildings exhibit attractive details that are difficult to find in other similar complexes in Poland, including brick skirts, cornices, and surrounds of main entrances and gates. All buildings are compositionally coordinated. Another complex that is highly appreciated both by architects and urbanists is the bomb depot in Stara Łubianka. Its most noteworthy feature is the geometric watch tower that had been laid out on a polygon, accentuated with skirts, the texture of the white brick, and rhythmic daylighting of the staircase. It is located in the northern corner of the plot, thus acting as a spatial marker of the entire complex.

6 . The study revealed that some post-military facilities are not suitable for the organization of paramilitary competitions. The reason for this unfitness may be the limited area, inability to meet safety requirements, or unattractiveness of the game field.

7. Fort VIIa in Poznań, the bomb depot in Stała Łubianka near Piła, and the nuclear missile base in Brzeźnica-Kolonia belong to one of the most attractive post-military areas that are adaptable to the needs of paramilitary sports. These are followed by the Fort Ia "Boyen" in Poznań, the infantry shelter at Gołężycka street in Poznań, the interfield shelter of Fort II near the weir on the Cybina river in Poznań, the decommissioned base of the 77th Air Defense Missile Division in Złotkowo, and the Officers' Mess in Biedrusko.

8. The analysis of all 43 facilities demonstrated that 8 of them require urgent intervention, while 5 others should undergo major refurbishment. The Officers' Mess in Biedrusko, the Fort Ia "Boyen" in Poznań, the base of the 77th Air Defense Missile Division in Złotkowo near Poznan, and barracks at Kołobrzeska Street in Piła belong to the complexes of unique and highly appreciated architectural value. Unless re-employed, they will continue to fall into ruin.

On the ground of the General Airsoft Statistics Report, published by the Center for Airsoft Statistics and Player Relations, it may conclude that paramilitary sports remain elitist. Airsoft players are usually entrepreneurs and full-time workers who on average earmark $\$ 2000$ for the necessary gear and equipment alone. Large sums of money are also invested in military vehicles that are customized to the needs of airsoft games, firearm replicas, and traveling to the venues of airsoft competitions. Players from the United States and Western European countries lead the way in such spendings. The adaptation of post-military facilities in Poland for the purpose of serving these customers may not only protect architecturally valuable structures, but also - analogically to golf courses - contribute to the economic stimulation of nearby towns.

The results of the analysis of the adaptability of disused post-military areas as paramilitary sports centers as well as the presented examples of such facilities, that already operate, constitute a confirmation of the assumed thesis: The theoretical model of paramilitary sports centers is a helpful tool in the process of evaluating the suitability of the given facility for the organization of Airsoft games and helps properly develop the area in terms of its functionality and spatial lay-out.

The presented method may be employed as the tool for selecting historic post-military sites around the country that should undergo revitalization by means of hosting airsoft games.

\section{Financing}

Studies have been conducted within the framework of the 
DS.MK 2015 research grant - "Military architecture as an environment for airsoft games", realized at the Faculty of Architecture of the PUT.

\section{REFERENCE}

[1] Biesiadka J., Gawlak A., Kucharski Sz., Wojciechowski M.: Twierdza Poznań - O fortyfikacjach Miasta Poznania w XIX i XX wieku, Wydawnictwo Raweli, Poznań 2006, p. 161.

[2] Jarczewski W.: Przestrzenne aspekty rewitalizacji śródmieścia, blokowiska, tereny poprzemysłowe, pokolejowe i powojskowe, [Spatial revitalisation aspects - city centres, estates, post-industrial, railway and military areas] Vol. 4, Published by The Urban Development Institute, Kraków 2009, p. 243.

[3] Virilio P.: Bunker Archeology, Princeton Architectural Press, New York 2008, Reprint of Virilio Paul: Bunker archéologie, Editions Galilée, Paris 1975.

[4] Wolfs R.: Waterliniepad: wandelenlangs de NieuweHollands ewaterlinie (Themapad (2)), Willems adventure publications, 2004, ISBN 90-71068-61-7.

[5] Klinkert, W.: Het Vaderland Verdedigt (Bijdragen SMG), SectieMilitaireGeschiedenis1992, ISBN 90-70677-29-6.

[6] Hercik Jan, Šimáček Petr, SzczyrbaZdeněk, Smolová Irena: Military Brownfields in The Czech Republic and the potential for their revitalisation, focused on their residential function, QuaestionesGeographicae 33(2) • 2014.

[7] Hercik Jan, Szczyrba Zdeněk: Post-military areas as space for buisness opportunities and innovation, PraceKomisjiGeograf iiPrzemysłu nr 19, Warszawa-Kraków 2012.

[8] Hercik Jan, ŠerýOndřej, ToušekVáclav: Post-Military Areas in The Czech Republic and their revitalization - examples of The Towns of Hodonín and UherskéHradiště, ActaUniversitatisPalackianaeOlomucensis-Geographica, Vol. 42, No. 2, 2011, pp. 107-119.

[9] Nepravishta Florian: Regeneration of military brownfield heritage in Albania, [dostęp: 30.11.2014] Browninfo, source: http://www.academia.edu/7888923/REGENERATION OF MILITARY_BROWNFIELD_HERITAGE_IN_ALBĀNIĀ.

[10] Bara Simona, Antal Alexandra, Barbu Mariana:
Patrimoniulprovenit din fostelebazemilitaretrecuteîn circuit civil întrerealitateşiuitare, Urbanism. Arhitectura. Constructii, 2010, Vol. 1(1), p.25.

[11] US Environmental Protection Agency „Turning Bases: Into great places: New Life for Closed Military Facilities [dostęp: 30.11.2014] dostępny w Internecie: http://www.epa.gov/dce d/pdf/ bases_into_places.pdf.

[12] Lisa Anna (2012), “inhabitat.com/Atelier-f Transforms Old Swiss Military Bunker into a Vibrant Green-Roofed Cultural Center", URL: http://inhabitat.com/atelier-f-transforms-old-s will-military-bunker-into-a-vibrant-green-roofed-cultural-ce nter/atelier-f-recycled-military-building-angebauter-tarnruck sack-1/.

[13] URL: http://www.archello.com/sites/default/files/imagecache /header_detail_large/story/media/resized14_86.jpg (2015).

[14] ASCEND (2014), “Achieving the Socio-Economic Re-use of Former Military Land and Heritage. Model Management Framework, Medway Council", Pp. 2, URL: http:/urbact.eu/fileadmin/Projects/REPAIR/ documents media/Ascend_Repair.pdf.

[15] URL: http://www.oea.gov/about/oea (2014).

[16] “1988, 1991, 1993 and 1995 BRAC ACTIONS - BASE REUTILIZATION STATUS, (Major Base Closures and Realignments as of December 31, 2007)", URL: http://www.oea.osd.mil/library/directory/assistance /brac/past-brac-experiences.

[17] URL: http://www.battle-union.jp (2014).

[18] Jarczewski W.: Przestrzenne aspekty rewitalizacji śródmieścia, blokowiska, tereny poprzemysłowe, pokolejowe i powojskowe, [Spatial revitalisation aspects - city centres, estates, post-industrial, railway and military areas] Vol. 4, Published by The Urban Development Institute, Kraków 2009 , p. 251

[19] Socha Piotr (2011), "Rola organizacji paramilitarnych w systemie obronnym kraju", URL: http://portal.zs-strzelec.mil .pl/artykuly/inne/464-rola-organizacji-paramilitarnych-w-sys temie-obronnym-kraju.

[20] Bańko Mirosław (2001), “paramilitarny”, URL: http://poradnia.pwn.pl/lista.php?id=522.

[21] General Airsoft Statistics Report. (2013), Wyd. TCASPRPub. 2013/08 Dallas, 2013. 